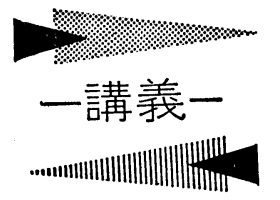

1. ま えがき

金属材料や保温材，耐火棟虐，核燃料など舶用機関 の構成材料のほとんど全部は, 多少の差こそあれ, 温 度変化により必ず熱膨張, 収縮を伴うので, それらの 材料よりなる部材の温度分布が一様でないときは，そ の内部に応力やひずみを生じ，それを熱応力，熱ひず みという。

定常熱伝導温度場によって, 定常的に生じている熱 応力を定常熱応力と呼び, また, 機器の始動, 停止時 や負荷変化時に生ずる非定常熱伝導温度場によって生 ずる熱応力を非定常熱応力と呼ぶ.

非定常熱応力のうち, とくに急激な加熱, 冷却によ って生ずる熱応力の過渡的ピークを熱衝撃（サーマル ショック）と称する.

熱応力はとくに機器の大形化, 高熱負荷化, および 負荷変化の急激化に伴って増大し, 近年のように巨大 化しかつ大出力化する舶用機関 (タービン, ボイラ,デ イーゼル) や各種舶用熱機器 (熱交換器, 冷凍機, LPG, 油加熱) などにとって特に重要である.

また, 熱応力は内部圧力や自己重量などによる機械 的応力と合成されて考えられるときには, 合成応力の 限界値より逆に熱応力がきまり, ひいては, 機器の許 容熱負荷限界を定める要因となる.

本講義に执いては，まずその一にて代表的な定常熱 応力, 非定常熱応力などについて説明した後にその二 にて熱負荷限界などについて言及したい.

なお, 熱応力の解法については, 近来, 電子計算器 を駆使する有限要素法などの計算法が進展している が，この講義は解法よりもむしろ大局的なは握を目的 として熱応力と熱限界の基礎的な概念の説明を中心と して取り扱いたいと思う。また, 筆者は熱工学を専門 とするので説明が在来の材料力学的な考えとは若干異 なるかも知れないがお許しを願いたい。

\section{2. 熱応力の基礎式}

いま，材料が全く無拘束で自由に熱膨張すると仮定 したときの単位長さ当たりの熱膨張割合, すなわち,

*原稿受付 昭和45年11月17日

**正会 員 東京工業大学工学部 (東京都目黒区大岡山 2-12-1)
自由熱ひずみを $\varepsilon_{F T}$ とし, その材料の基準值からの温 度上昇を $T^{\circ} \mathrm{C}$ とするときは,

$$
\varepsilon_{F T}=\beta T
$$

である.ここで $\beta$ はその材料の熱膨張率 $\left(1 /{ }^{\circ} \mathrm{C}\right)$ で ある。

また，その材料が別に拘束もしくはなんらかの外力 を受けていることによって発生する拘束ひずみを $\varepsilon_{R S}$ とすると, 実際の見かけのひずみ $\varepsilon_{A C}$ は両者の和であ っ ,

$$
\varepsilon_{A C}=\varepsilon_{F T}+\varepsilon_{R S}
$$

である.これらのひずみのうち材料内部に実際に応力 を発生させるのは $\varepsilon_{R S}$ であって, 通常は $\varepsilon_{F T}$ がまず (1)式により与えられ，また， $\varepsilon_{A C}$ が外的な拘束条件に よって与えられてくると(2)式より $\varepsilon_{R S}$ が間接にきまっ てくる.すなわち，

$$
\varepsilon_{R S}=\varepsilon_{A C}-\beta T
$$

である. $\varepsilon_{R S}$ がきまれば応力が求められる.

平面応力では, 主応力方向を 1,2 とし, 主応力を $\sigma_{1}, \sigma_{2}$, その方向の $\varepsilon_{R S}, \varepsilon_{A C}$ を $\varepsilon_{R_{1}}, \varepsilon_{R 2}, \varepsilon_{A C_{1}}, \varepsilon_{A C_{2}}$ とすると, 平面応力の基礎式よりレをポアソン比とし て,

$$
\begin{gathered}
\sigma_{R_{1}}=\frac{E}{1-\nu^{2}}\left(\varepsilon_{R_{1}}+\nu \varepsilon_{R 2}\right) \\
\sigma_{R_{2}}=\frac{E}{1-\nu^{2}}\left(\varepsilon_{R_{2}}+\nu \varepsilon_{R_{1}}\right)
\end{gathered}
$$

でありまた，(3)式より

$$
\begin{aligned}
\varepsilon_{R_{1}} & =\varepsilon_{A C_{1}}-\beta T \\
\varepsilon_{R_{2}} & =\varepsilon_{A C_{2}}-\beta T
\end{aligned}
$$

である.

ここで温度 $T$ の分布は熱伝導の理論によって与えら れ，一般には， $a$ を温度伝導率， $\Delta$ をラプラシアンと して,

$$
a \Delta^{2} T=\frac{\partial T}{\partial t}
$$

で表現される。

熱応力を知るには，まず(7)式と熱的境界条件とから $T$ のある時刻における分布 $T(x, y)$ を知り, ついで 時間を固定しておいて,そのときの拘束条件より $\varepsilon_{A C_{1}}$, $\varepsilon_{A C_{2}}$ を知って式(4)ないし(6)より $\sigma_{R_{1}}, \sigma_{R_{2}}$ を求めれば よい. 


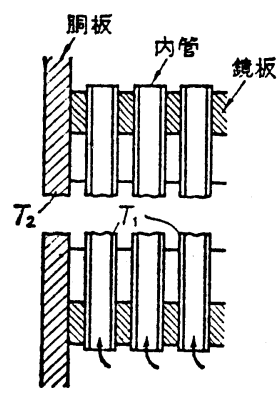

(a) シェルアンドチュ ーブ形熱交換器

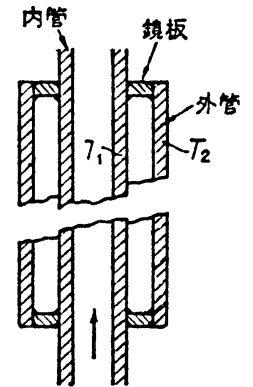

(b) 二重壁熱交換器

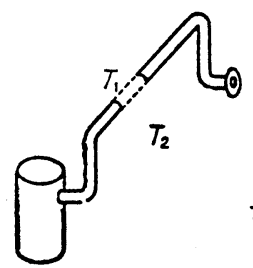

(c) 高温配管

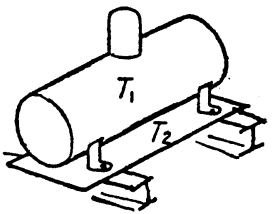

(d)高温機器の支持

図 1 二本柱モデルで置き換えできる定常熱応力発生例

\section{3. 定常熱応カ}

3.1 定常熱応カについて 温度分布が時間ととも に変化しないときの熱空力を定常熱応力と称する.

定常熱応力は, 機器が定常的に作動しているときに 存在し，その定常的熱ひずみや性能に関係する.

3.2 二本柱モデル 定常熱応力のうち, よく出現 するのは簡単な二本柱モデルで置き換えられる熱交換 器やダクトなどの構造的一次元熱応力である.

いま，図1(a)のようなシェルアンドチューブ形熱交 換器, (b)のような二重壁熱交換器の内外筒, 同図(c), (d)のような高温配管や機器の支持部などに生ずる長手 方向熱応力は, 図 2 のような二本柱モデルに置き換え できる.

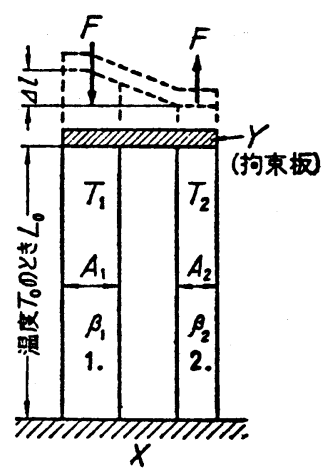

図 2 二本柱モデル

そのモデルは断面が $A_{1}, A_{2}$, ヤング率 $E_{1}, E_{2}$, 熱 膨張系数 $\beta_{1} ， \beta_{2}$ ，なる二本の柱 $1 ， 2$ があって，それ らの下方が底面 $X$ で固定され, 上方が拘束板 $Y$ で両者 が連結され，かつ，Yは両者の相対伸びに対してそれ に反抗する反力 $F$ を生ずるとするものである。 二本の 柱は長手方向の管などに, また拘束板 $Y$ は鏡板, 腕 板，ベローズなどに対応するものである.
いま，はじめ両者が基準温度 0 のときに両者の長さ が $L_{0}$ で等しいものとし，その後，柱 $1 ， 2$ はそれぞ れ平均温度 $T_{1}, T_{2}$ なる定常温度に保たれるものとす る.

いま, 拘束板の $y$ 方向の相対見かけの変位を $\Delta l$ と して, 反力を $F$ とするとき, 拘束板 $Y$ の剛性 $K_{S T}$ を 次式で定義する。

$$
F=K_{S T} \Delta l
$$

いま, 柱の中の応力として長手方向の主応力 $\sigma$ だけ を考え, 傍字 $1 ， 2$ をもって柱 $1 ， 2$ に属する值を示 すむのとすると, 式(6)より

$$
\begin{aligned}
& \varepsilon_{R S_{1}}=\frac{\sigma_{1}}{E_{1}}=-\frac{F}{A_{1} E_{1}}=\varepsilon_{A C_{1}}-\beta_{1} T_{1} \\
& \varepsilon_{R_{2}}=\frac{\sigma_{2}}{E_{2}}=\frac{F}{A_{2} E_{2}}=\varepsilon_{A C_{2}}-\beta_{2} T_{2}
\end{aligned}
$$

が成立し, かつ, 見かけひずみはその差 $\Delta l$ が(8)式で きまってくるので, $\beta_{1} T_{1}>\beta_{2} T_{2}$ として

$$
\varepsilon_{A C_{1}}-\varepsilon_{A C_{2}}=\frac{\Delta l}{L_{0}}=\frac{F}{K_{S T} L_{0}}
$$

である. いま, 式(9)，(10)，(11)より $\varepsilon_{A C_{1}}, \varepsilon_{A C_{2}}$ を消去 すると, $F_{0}, \sigma_{1}, \sigma_{2}$ は

$$
\left.\begin{array}{c}
F=\frac{\beta_{1} T_{1}-\beta_{2} T_{2}}{\left(\frac{1}{K_{S T} L_{0}}+\frac{1}{E_{1} A_{1}}+\frac{1}{E_{2} A_{2}}\right)} \\
\sigma_{1}=-F / A_{1} \text { (圧縮) }, \sigma_{2}=F / A_{2} \text { (引張り) }
\end{array}\right\} \cdots \text { (12) }
$$

で計算されることになる.

とくに， $\beta_{1}=\beta_{2}, E_{1}=E_{2}$ と考えられるときは， $T_{1}-T_{2}=\Delta T$ とおいて,

$$
\sigma_{1}=-\frac{A_{2}}{A_{1}} \sigma_{2}=-\frac{\beta_{1} \Delta T}{\frac{A_{1}}{K_{S T} L_{0}}+\frac{1}{E_{1}}\left(1+\frac{A_{1}}{A_{2}}\right)}
$$

となる. 本式を無次元表示すると

$$
\begin{aligned}
& k_{S T}=\frac{L_{0} K_{S T}}{A_{2} E} \\
& A / A_{2}=\psi
\end{aligned}
$$


となる.

$$
\left.\begin{array}{l}
\frac{\sigma_{1}}{\beta \Delta T E_{1}}=-\frac{1}{1+\psi+1 / k_{S T}} \\
\frac{\sigma_{2}}{\beta \Delta T E_{1}}=\frac{\psi}{1+\psi+1 / k_{S T}}
\end{array}\right\}
$$

とくに， $k_{S T} \doteqdot \infty$ すなわち, 拘束板が剛体のときは,

$$
\frac{\sigma_{1}}{\beta \Delta T E_{1}}=-\frac{1}{1+\psi}=-\frac{\sigma_{2}}{\psi \beta \Delta T E_{2}}
$$

となって， $\sigma_{1}, \sigma_{2}$ のうちの絶対值の大きいほうの值が 最小となるのは $\phi=1$, すなわち, $A_{1}=A_{2}$ のときで ある. また拘束板が可挩性を有して $K_{S T}$ が十分小さ いときは, $\sigma_{1}, \sigma_{2}$ は

$$
\frac{\sigma_{1}}{\beta \Delta T E_{1}} \doteqdot-k_{S T}=-\frac{\sigma_{2}}{\psi \beta \Delta T E_{2}}
$$

に漸近して， $k_{S T}$ が小さいほど応力が小さくなること がわかる。

以上から二本柱熱応力の軽減法の一つは, $A_{1}=A_{2}$ と することであり，もう一つは $k_{S T}$ を小さくすること で，その後者は拘束板を心゙ローズや可暁板のような可 捹性のものにすることを示さしている.

実際上は図 3 の上うな各種の可暁部材や可暁構造が 熱応力緩和に使用されている.

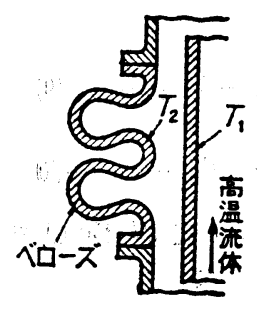

(a) ペローズ

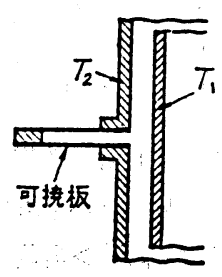

(b) 可㜔板

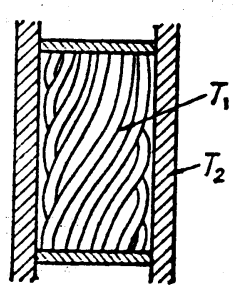

(c) 曲管熟交挜器

图 3 可搷部材や構造の例

3.3 定常熱流束による平板内 の定常熱応力 W ま, 図 $4(\mathrm{a})$ のうに, 厚さ $L[\mathrm{~m}]$ なる板がその板に 垂直方向に $q$ なる定常熱流束をもつときは，その温度 分布は直線的で, いま, 高温側を $T_{1}$, 低温側を $T_{2}$ と ᄂ, $x, y, z$ 座標の $z=0$ なる点を板の厚さの中心部 とすると, 温度 $T$ の分布は明らかに,

$$
\left.\begin{array}{l}
T=T_{\mathrm{C}}+\frac{Z\left(T_{1}-T_{2}\right)}{L}, T_{1}-T_{2}=q L / \lambda \\
T_{0}=T_{1}+T_{2} / 2
\end{array}\right\}
$$

で与えられる。

もしこのような板が全く拘束をされていないとする と, 主応力方向を $x, y$ とし, $\varepsilon_{R s_{1}}=0, \varepsilon_{R s_{2}}=0$ であ るので6式より，

$$
\varepsilon_{A C}(x \text { もしくは } y)=\beta T=\beta T_{0}+\beta \frac{z}{L}\left(T_{1}-T_{2}\right) \cdots(19)
$$
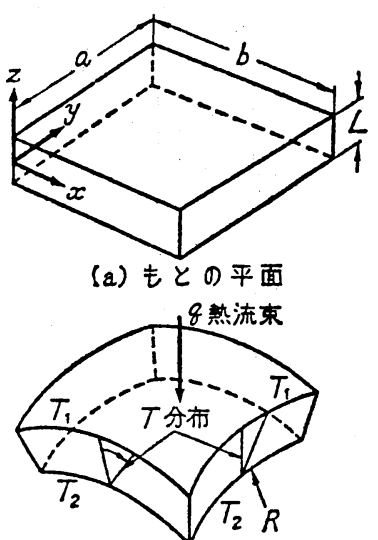

（b）加䓡して㛃拘束時の曲り

図 4 垂直な定常熱流を受ける 平板の熱ひずみ

となって，板全体として，まず， $\beta T_{0}$ だけ伸びた上 に， $Z$ 方向に $Z$ に比例するなど傾斜の不均一伸びを生 ずる.

この伸びは板に同図(b)のように $1 / R=\beta\left(T_{1}-T_{2}\right) / L$ なる曲率の球面状の熱ひずみを与える.

もし, この板が板状熱交換器の板面や, シェルアン ドチューブ熱交換器の鏡板のようにと考えられるとき は, $\beta T_{0}$ までの熱膨張を差し引いた残 り の見かけひずみが, $\varepsilon_{A C_{x}}=0, \varepsilon_{A C y}=0$ でな ければならないので，(4)，(5)，(19)式より $\sigma_{x}, \sigma_{y}$ は

$$
\begin{aligned}
\sigma_{x} & =\sigma_{\nu}=-\frac{E}{1-\nu^{2}} \beta T(1+\nu) \\
& =-\frac{E}{(1-\nu)} \frac{\beta_{z}\left(T_{1}-T_{2}\right)}{L} \cdots(20)
\end{aligned}
$$

となる. このときの最大熱応力 $\sigma_{T_{\max }}$ は板 の両面 $(z= \pm L / 2)$ で生じ,

$$
\begin{aligned}
\sigma_{T_{\max }=} & \pm \frac{1}{2(1-\nu)} E \beta\left(T_{1}-T_{2}\right)= \\
& \pm \frac{E \beta L q}{2(1-\nu) \lambda} \quad \ldots \ldots \ldots . . .
\end{aligned}
$$

である. (211式より熱応力は, また, 定常熱負荷 $q$ によ ってきまることに注目する必要がある.

3.4 円管に生ずる定常熱応力 図 5 のような断 面が同心円の円管が半径方向に一様な定常熱流束を有 し, しかも, 円管が十分長くて長手方向の伸びが点線 で示すようにすべての部分で一様であると考えられる ときは，管の材料内部の半径方向温度分布に対応して 管の材料内に 円周方向熱応力 $\sigma_{t t}$ と半径方向熱応力 $\sigma_{t r}$ 軸長手方向熱応力 $\sigma_{t z}$ が生ずる.

まず, このさいの管内の温度分布は, 管の内壁温度 を, $T_{1}$, 外壁温度を $T_{2}$ とし, $T_{2}>T_{1}$ とすると, 半 


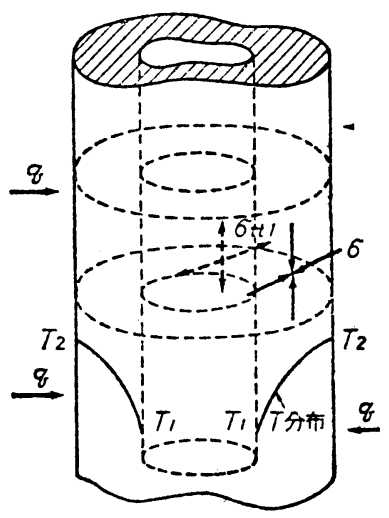

図 5 円管に生ずる熱応力

径 $r$ において

$$
T=\frac{T_{2} l_{n}\left(r / r_{1}\right)+T_{1} l_{n}\left(r_{2} / r\right)}{l_{n}\left(r_{2} / r_{1}\right)}
$$

で与えられている，式(4)，(5)を円筒座標に直したもの において軸方向の見かけの伸びが一様であり，また， 角 $\theta$ 方向の見かけのひずみがないという条件を入れて 解くと, $\sigma_{t r}, \sigma_{t t}$ は

$$
\begin{aligned}
\sigma_{t r} & =\frac{E \beta\left(T_{2}-T_{1}\right)}{2(1-\nu) l_{n}\left(r_{2} / r_{1}\right)}\left[-l_{n} \frac{r_{2}}{r}\right. \\
& \left.-\frac{r_{1}^{2}}{r_{2}^{2}-r_{1}^{2}}\left(1-\frac{r_{2}^{2}}{r_{2}}\right) l_{n} \frac{r_{2}}{r_{1}}\right] \\
\sigma_{t t} & =\frac{E \beta\left(T_{2}-T_{1}\right)}{2(1-\nu) l_{n}\left(r_{2} / r_{1}\right)}\left[1-l_{n} \frac{r_{2}}{r}\right. \\
& \left.-\frac{r_{1}^{2}}{r_{2}^{2}-r_{1}^{2}}\left(1+\frac{r_{2}^{2}}{r_{2}}\right) l_{n} \frac{r_{2}}{r_{1}}\right] \\
\sigma_{t_{z}} & =\frac{E \beta\left(T_{2}-T_{1}\right)}{2(1-\nu) l_{n}\left(r_{2} / r_{1}\right)}\left[1-2 l_{n} \frac{r_{2}}{r}\right. \\
& \left.-\frac{2 r_{1}^{2}}{r_{2}^{2}-r_{1}^{2}} l_{n} \frac{r_{2}}{r_{1}}\right]
\end{aligned}
$$

となり，これらの諸忍力のうち，極大值は管の内面と 外面に生ずる接線応力 $\sigma_{t t}$ であって,

それぞれを $\sigma_{t t 11}, \sigma_{t+2}$ とすると，

$$
\left.\begin{array}{c}
\sigma_{t t 1}=\xi_{1} \frac{E \beta\left(T_{2}-T_{1}\right)}{2(1-\nu)} \text { (引張り) } \\
\sigma_{t t 2}=-\xi_{2} \frac{E \beta\left(T_{2}-T_{1}\right)}{2(1-\nu)} \text { (圧 縮) }
\end{array}\right\} \cdots \cdots \text { (24) }
$$

\begin{tabular}{c|c|c}
\hline$r_{2} / r_{1}$ & $\xi_{1}$ & $\xi_{2}$ \\
\hline 1.0 & 1.000 & 1.000 \\
1.1 & 1.032 & 0.968 \\
1.2 & 1.061 & 0.939 \\
1.5 & 1.134 & 0.866 \\
2.0 & 1.224 & 0.776 \\
3.0 & 1.340 & 0.660 \\
4.0 & 1.412 & 0.588 \\
\hline
\end{tabular}

である。ここで $\xi_{1} ， \xi_{2}$ は $r_{2} / r_{1}$ の関数で表 1 のよう な值で示されている.

\section{4. 非定常熱応力（熱衝撃）}

4.1 熱衝撃について タービン車室のフランジや 大形止弁や大形ディーゼルピストンのような厚肉部材 に急速起動時などの急激な温度变化を与えると，ひび 割れを生ずる危険がある。

また，ボイラの耐火れんが内張りのようなセラミッ ク材料も急速加熱や泠却時にひびわれが生ずることが 多い.

一般に急激な加熱や冷却や負荷変化に伴ら非定常温 度分布によって過渡的に大きな熱応力が生ずることが 多いが，このような非定常熱応力を熱衝撃と呼ぶ.

通常，いかに急激な熱膨張でも，そのさいの変位に よる運動エネルギは無視できるので，非定常熱応力は 特別な場合をのぞき, 温度分布の時間変化が与えられ れば，各瞬間の温度分布に対応する熱応力を定常時と 同様に計算して，それを順次つなげばよい.

いま，物体の代表長さを $L$ （たとえば板の厚さ）と し，表面から熱伝達率 $\alpha$ をもつ流体で急激に加熱また は冷却するとき，その物体の熱伝導率を $\lambda$, 温度伝導 率を $a$ とするとき内部の非定常温度 $T$ の分布の経時変 化はさきの(7)式を解くことで与えられるが，その変化 状況は

$$
\begin{aligned}
& B i(\text { ビオー数 })=\frac{\alpha L}{\lambda} \\
& F r(\text { フーリエ数 })=\frac{a t}{L^{2}}
\end{aligned}
$$

なる二つの無次元数の関数となる. ここでビオー数 は，表面熱伝達の良否の影響を示し，フーリエ数は無 次元時間であって最大の熱衝撃が発生するまでの時間 に関係する無次元数である.

4.2 熱伝達による板の急加熱時の熱衝撃 図6の ように厚さ $L$ な平板がはじめ温度 $T_{o}$ で一様のとき,

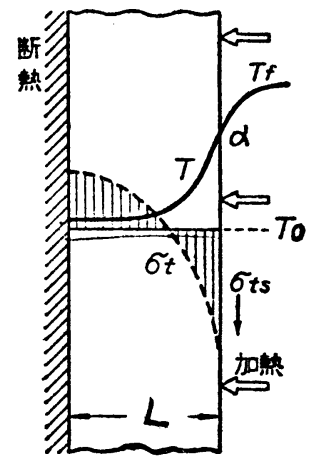

図 6 平板の熱伝達による急激加熱 
$t=0$ から温度 $T_{f}$ なる流体を片面にもってきて熱 伝達率 $\alpha$ に急激に加熱し，かつ，他面を断熱とする とその内部に温度変化が生じて, その温度分布に対応 する熱灾力はさきの(4)ないし(6)式と拘束条件からきま る.

拘束条件としては板の長手方向の伸びと曲がりを自 由にするとき（曲がり自由）と，板の長手方向の伸び を自由にして曲がりを拘束するとき（曲がり拘束）の 二つが考えられ，とくに曲がり拘束のときの応力分布 は厚さ $2 L$ なる板が両面より加熱されるときと全く同 じになる。

いま，このような加熱によるさいの熱応力を計算す ると，各瞬間における最大応力は必ず表面で生じてい る接線方向応力であり，その值を $\sigma_{t o}$ とすると， $\sigma_{t o}$ は時間の関数であって，

いま, $\sigma_{t o}$ を含む無次元応力 $\sigma_{t} *$ を，

$$
\sigma_{t} *=\frac{\sigma_{t_{0}}(1-\nu)}{E \beta\left(T_{f}-T_{o}\right)}
$$

のように作ると， $\sigma_{t}^{*}$ は(25)，(26)式による $B i$ およよ゙ $F r$ の関数となり，Fr を横軸として曲がり拘束および曲 がり自由に対し，図7のようになる。

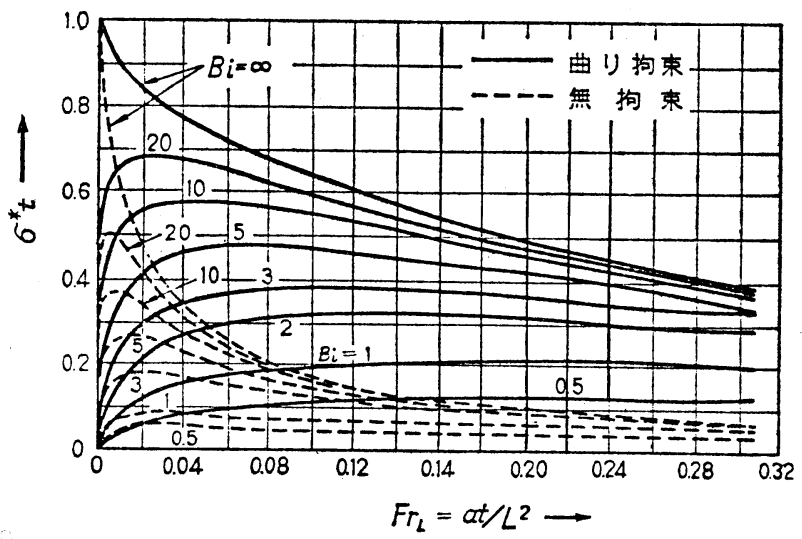

図 7 板の片面よりの急激加熱時の表面無次元熱応力 の $\mathrm{Fr}$ 数による変化

4.3 板の表面温度を一定割合で上昇するときの非 定常熱応力 依，厚さ $L$ なる片面断熱の板の他面 か，もしくは厚さ $2 L$ なる板の両面の温度を図 8 のよ うに時間 $t=0$ より一定速度で上昇し, $t=t_{E}$ にお いて表面温度 $T_{f}$ とし，その後は $T_{f}$ に保っものと

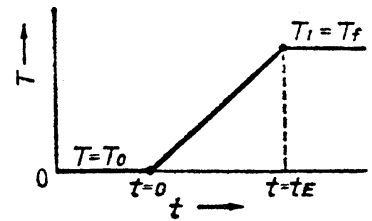

図 8 板の表面温度の一定割合上昇
するときの非定常熱応力を求める.

このときの最大熱応力は加熱終了時における板表面 にy 方向応力として生じ，それを $\sigma_{t o}$ として，さきの (27)式と同椂な無次元応力 $\sigma^{*}$ を作り, また, 時間 $t_{E}$ によってフーリエ数 $F r_{L}{ }^{*}=a t_{E} / L^{2}$ を作ると， $\sigma^{*}$ は $F r_{L}{ }^{*}$ の関数となって図 9 のように表わされる.

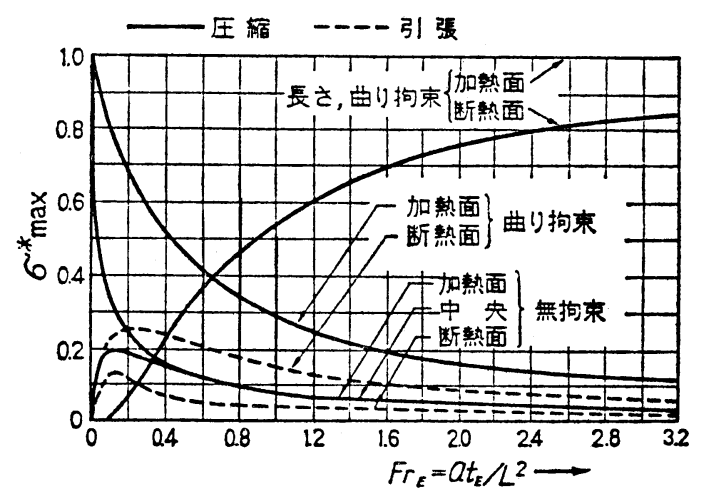

図 9 板の表面温度を一定割合で上昇させた ときの無次元熱応力

同図には片面断熱，片面加熱の場合を長さを拘束し ないで曲がり拘束と曲がり無拘束にしたと き，および長さも曲がりも拘束したときの 三つに分けて示してある. 罒のよらに長さ 方向伸びも押さえたときが最も忘力が大き いが，これはむしろ二本柱問題に属するも のとなる。

4.4 両側を熱伝達によって急激加熱(冷 却される平板に生ずる熱応力 タービン 車室壁, ボイラ壁, あるいはディーゼルピ ストン壁など熱衝撃が問題となる部材はす ベて，たとえ一方が急加熱されても他方が やはり冷却されていることが多く，単に片 側断熱と考えられないことが多い，そのた

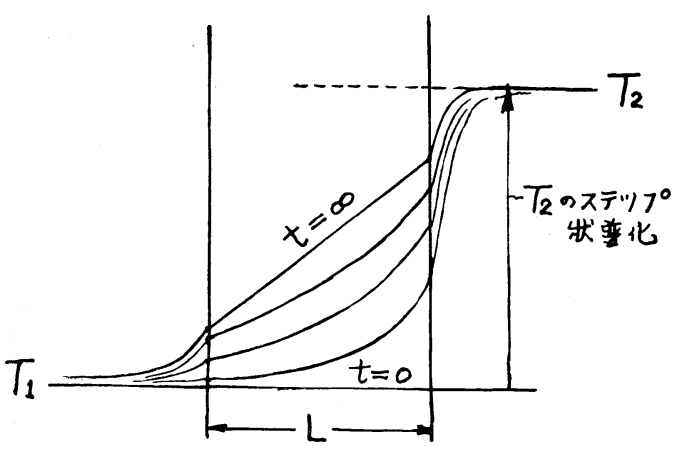

図10 両側に熱伝達がある板の片側温度が 急上昇するさいの状況 


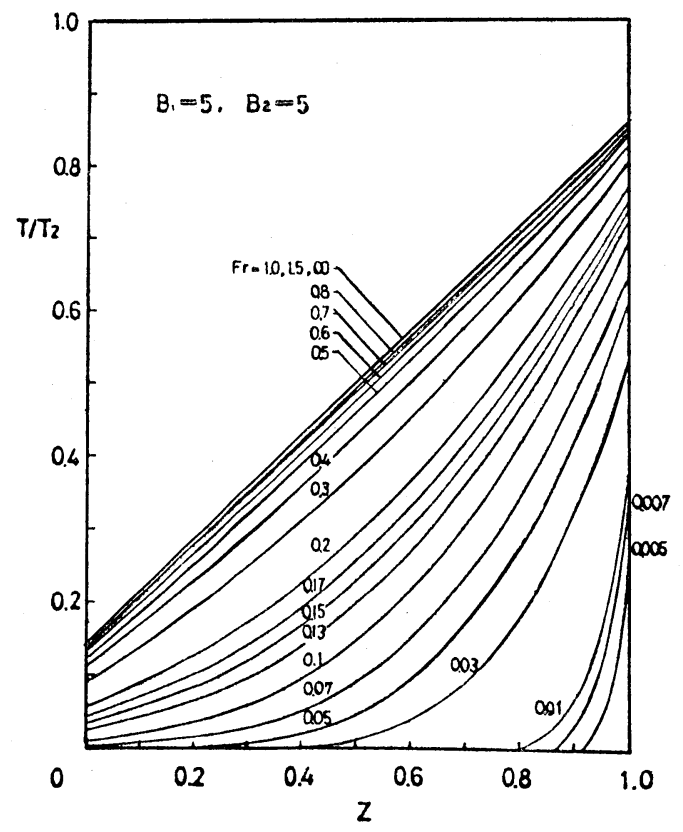

(a)

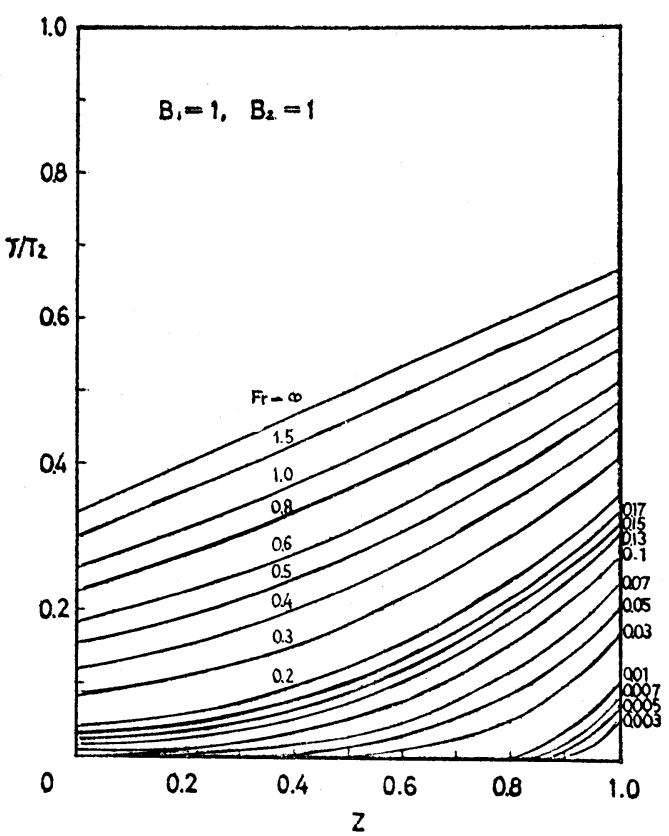

(b)

図11両側より熱伝達をうける板の片面温度が急変化したときの板の内部温度の経時変化

め, さらに問題を一般化して両側に熱伝達があるとき を考える。

いま，図10のように厚さ Lなる板の両側がそれぞれ 熱伝達率 $\alpha_{1}, \alpha_{2}$ なる流体と接触していて, $t=0$ よ り急激に片側 ( $\alpha_{2}$ 側) の流体の温度 $T_{2}$ だけがステッ プ状に変化するときを考える.

$T_{1}$ が一定に保たれているので，この変化は時間が 十分に経過すれば定常熱通過の状況となる. しかし, それまでの内部温度の変化状 況は左右の流体の熱伝達率に 強く影響をうけ，いま両側の 流体のビオ一数を

$$
B_{1}=\alpha_{1} L / \lambda, \quad B_{2}=\alpha_{2} L / \lambda
$$

とすると, $B_{1} B_{2}$ との組み合 わせによって温度分布はきま る.

いま, $Z=x / l$ なる 無次元 長さとしたときの内部温度の 計算例を図11(a)(b)に示す。 こ こで $F r$ は経過時間を示すフ 一リエ数で

$$
F r=a t / L^{2} \text { である. }
$$

さて, このさいの板材の内 部に生ずる熱応力を計算して
みると，板が曲がり拘束されているとして，その経時 変化状況は図12ないし図14に示すようになる.

ここで $\sigma^{*} t h$ は $\sigma_{t}$ を熱応力としたとき，

$$
\sigma^{*}{ }_{t h}=(1-\nu) \sigma_{t} / \beta E\left(T_{2}-T_{1}\right)
$$

なる無次元熱応力である.ここで $\sigma^{*}{ }_{t h}>0$ の側の值は 温度一定側, $\sigma^{*} t h<0$ の側は加熱側の無次元熱応力を 示す.

ここで図12は $B_{1}=0$ すなわち，冷却側が断熱のと

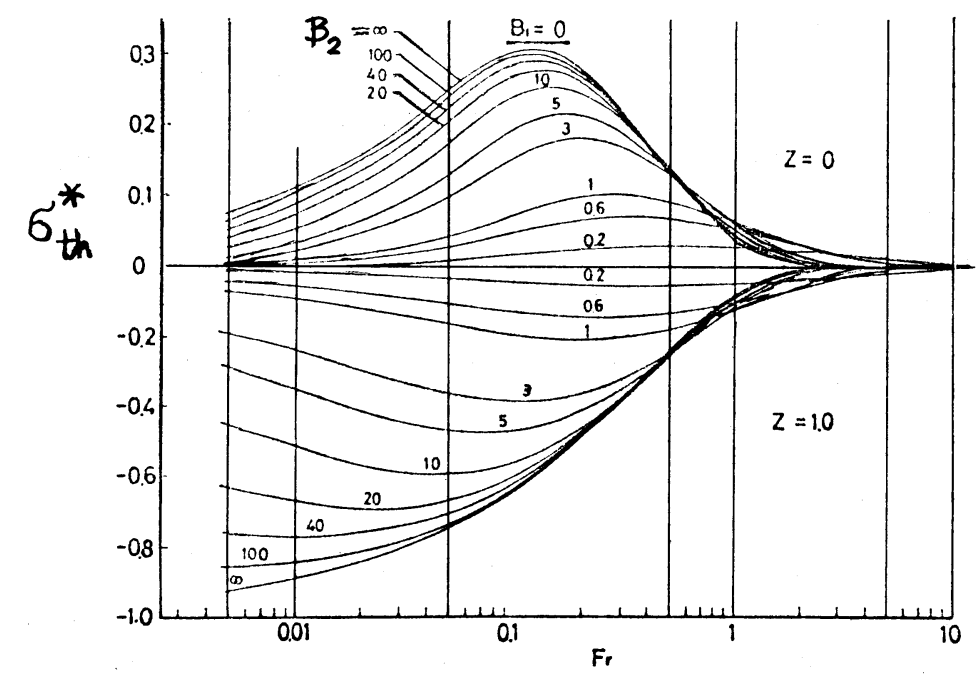

図12 $B_{1}=0$ のときの板内部の無次元熱応力の経時変化 


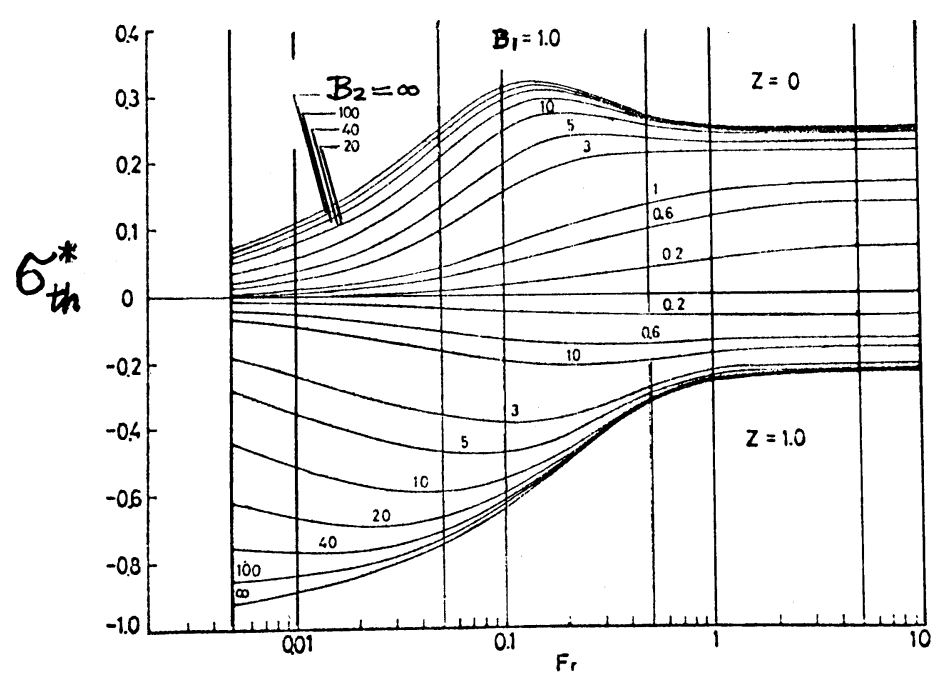

図13 $B_{1}=1.0$ のときの板内部の無次元熱応力の経時変化

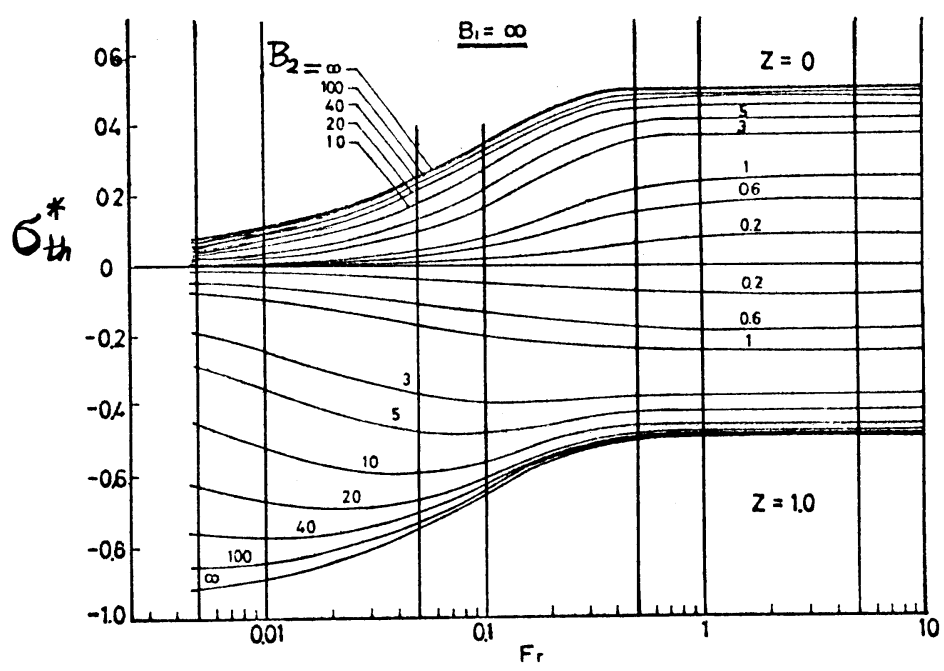

図14 $B_{1}=\infty$ のときの板内部の無次元熱応力の経時変化

きであり，図14は $B_{1}=\infty$ すなわち, 冷却側の熱伝達 率がきわめて高く壁温一定に保たれる場合であり, 図 13はこの二者の中間にはいる.

いずれの温度分布も $B_{2}$ の值をパラメータとして変 化していて $B_{2}$ が高いほど加熱側の熱伝達が良好であ ることを示している.

各図を見てわかるように，時間が十分経過すると $(F r>1)$ 応力は一定な定常值に収れんすることが示さ れるか，それに達するまでに一度ピークがある場合が 多い：このピークがすなわち熱衝撃を示すむのであっ て, $B_{1}$ が小さくて, $B_{2}$ が大きいほど, 熱衝撃の割合 が大きいことがわかる.

いま，熱衝撃の強さを示す一つのパラメータとし て, 熱衝撃比 $\xi$, すなわち, $\xi=$ 最大熱衝撃応力 (ピーク応力)

/最終定常束応力 (30) を導入する.

$\xi \geqq 1$ であればこの過程における熱応力は熱衝撃 のほうが大きいので過渡現象が重要であり，

$\xi<1$ であれば熱衝撃は問題にならずに定常熱応 力だけを取り上げればよい.

$\xi$ の值は $B_{1}{ }_{n} B_{2}$ の值によって定まり, 特に, 熱応 力の大きい $Z=1$ の面の側の $\xi$ の值の $B_{1} \sim B_{2}$ 平面上 の分布は図15のようになる。

一般に $B_{1}>0.5$ で $B_{2}<2$ の範囲，すなわち，急加 熱側の流体の熱伝達率が十分低く，しかも，冷却側の 流体の熱伝達率が十分高いときには， $\xi \leqq 1$ であっ て熱衝撃は考慮されなくてよい.しかし，逆のときは 
熱衝撃のほうが定常熱応力值より大きくな る.

\section{5. まと め}

まとめとして, 以上のような簡単な形状 で曲がりを拘束された部材に生ずる最大熱応 力を $\sigma_{\max }$ とするときは， $\Delta T_{\max }$ をその現 象において存在する最大の温度差とするとき は,

$$
\sigma_{\max }=\sigma_{\text {max }}^{*} \frac{E \beta \cdot \Delta T_{\max }}{(1-\nu)}
$$

なる簡単な形で表現できる。 ここで， $\sigma^{*}{ }_{\text {max }}$ は無次元熱灾力の最大值で

以上の例においては

(1) 剛体支持の構造的熱応力（二本柱モデ ル) では $\sigma_{\text {max }}^{*}=1 \sim 0.5^{(1-\nu)}$

(2) 平板定常熱応力 $\sigma_{\text {max }}^{*}=0.5$

(3) 円管定常熱応力 $\sigma^{*}{ }_{\text {max }}=0.5 \xi_{1}$ また は $0.5 \xi_{2}$

(4) 平板片面よりの急激熱伝達 $\sigma^{*}{ }_{\text {max }}=\sigma^{*}(B i)$ $\leqq 1.0$

(5) 平板片面の温度漸増 $\sigma^{*}{ }_{\text {max }}=\sigma^{*}(B i) \leqq 1.0$

(6) 平板両面の熱伝達 $\sigma^{*}{ }_{\text {max }}=\left(B_{1}, B_{2}\right) \leqq 1.0$

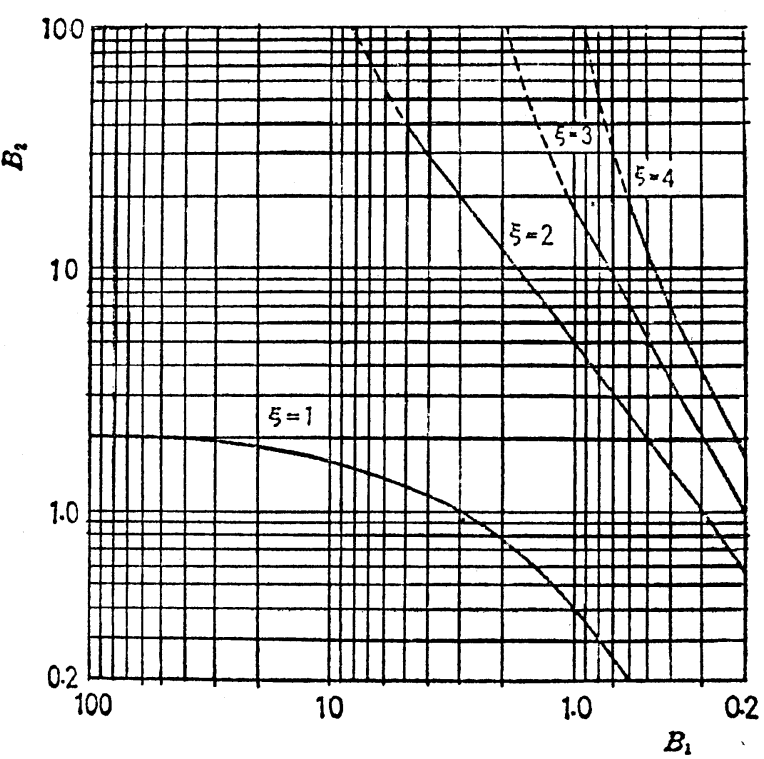

四15 $B_{1} ， B_{2}$ にたいする熱衝撃比 $\xi$ の值の分布 となって，以上の例ではいずれにおいても $\sigma^{*_{\text {max }}}$ は 1.0 上り小さい值であることがわかり実際上 $\sigma^{*}{ }_{\text {max }}=1$ とすることにより(31)式から熱応力の可能上限值が容易 に求められる。 